\title{
THE INFLUENCE OF VALGUS HEEL POSITION ON FOOT LOADING IN A CHILD'S GAIT
}

\author{
Eliška Martinásková, Lucie Honzíková, Miroslav Janura, Zdeněk Svoboda
}

Faculty of Physical Culture, Palacký University, Olomouc, Czech Republic

Submitted in November, 2012

BACKGROUND: Flat foot is a typical clinical sign in childhood, expressed as valgus positioning of the heel during vertical foot loading. This may lead to medial deviation of the foot axis and cause overloading of some foot areas.

OBJECTIVE: To determine the influence of valgus position of the heel (both bilateral and unilateral) on foot loading during gait.

METHODS: An experimental group consisting of children with bilateral heel valgus deformity (16 children, age $5.3 \pm 1.3$ years) and children with unilateral heel valgus deformity (14 children, age $5.6 \pm 1.6$ years). The control group comprised of 14 children (age $4.5 \pm 1.2$ years). For measuring foot loading during gait, the Footscan (RSScan International, Olen, Belgium) pressure plate was used. Each subject went through 8 trials of gait measurement. From each trial, 8 foot areas were evaluated. Data processing with mean values for each subject was performed by non-parametric tests (Mann-Whitney and Wilcoxon tests, Spearman correlation) in the STATISTICA programme (StatSoft, Inc., Tulsa, OK, USA).

RESULTS: Pressure peak and pressure impulse in the first metatarsal was greater for the bilateral valgus group $(p<0.01)$ in comparison to the control group. The group with unilateral valgus deformity showed greater pressure peak in the medial heel $(p<0.05)$, lower pressure peak in the third metatarsal $(p<0.01)$, lower pressure impulse in the fourth metatarsal $(p<0.05)$ and lower pressure peak $(p<0.05)$ and impulse $(p<0.01)$ in the fifth metatarsal on the limb with non-valgus position of heel when compared to the limb with valgus heel position.

CONCLUSION: The results show that valgus positioning of the heel influences foot loading in children during gait. The findings of this study suggest the necessity of a complex solution to the problem of preventing further progression of pathological changes.

Keywords: Calcaneus, vertical loading, gait cycle, dynamic plantography, pressure distribution.

\section{INTRODUCTION}

The number of children with foot deformities is on the rise. Many researchers have made the effort to find the causes of foot deformities and to create effective therapeutic approaches (Zafiropoulos, Prasad, Kouboura, \& Danis, 2009). The foot arch acts as a shockabsorber to maintain gait flexibility; therefore, any foot pathology can seriously affect the total body statics (Kapandji, 1987).

An important part of the foot shape development is the quality of the afferent adjustment. Sensory deprivation leads to reduced stimuli from the sole because lack of physical activity. Another major factor is the quality of the footwear influencing the shape of the child's foot (Chuter \& Janse de Jonge, 2012; Vařeka \& Vařeková, 2009).

Clinically, flatfoot gets manifested during vertical foot loading as valgus positioning of the heel with the partial disappearance of concavity of medial arch
(Vařeka \& Vařeková, 2012). The function of the foot arch to lower plantar loading in the metatarsal heads thus fails, and increased loading mainly in the medial part of the foot can be detected (Han, Koo, Jung, Kim, \& Lee, 2011; Ledoux \& Hillstrom, 2002; Valmassy, 1996).

The inverse position of the forefoot, with regard to the rearfoot at midtarsal joint (varus forefoot), increases due to inadequate torsion of the talus in the frontal plane during development. As compensation for this type of foot, so that the forefoot can support the body during contact with the mat (stance phase form), the valgus heel forms (Valmassy, 1996; Vařeka \& Vařeková, 2005).

Varus forefoot is characterized by reduced dorsiflexors activity during initial contact and loading response (Hoogvliet, van Duyl, de Bakker, Mulder, \& Stam, 1997; Perry \& Burnfield, 2010; Whittle, 1996). The following phase of the gait, where the flatfoot can cause some difficulties, is propulsion that the hypermobile Chopart's 
joint is unable to facilitate in the form of forefoot pronation and thus remains locked (Valmassy, 1996). During the propulsion, the foot fails in fulfilling the role of a rigid lever and causes overloading of the medial foot arch (Ledoux \& Hillstrom, 2002).

In children from 2 to 3 years, valgus heel can be considered as normal up to $15^{\circ}$ and as pathological from $20^{\circ}$ (Dungl et al., 2005). In adults, the normal value of heel valgus is considered up to $5^{\circ}$ (Vařeka \& Vařeková, 2009).

Foot function should be described in association with the load, inclusive of all compensations. Assessing the loading of a foot allows understanding the differences between the physiological and pathological patterns of the child's foot (Haris, Smith, \& Marks, 2008).

The aim of this study was to determine the influence of valgus heel position on foot loading and foot axis during gait.

\section{MATERIALS AND METHODS}

\section{Subjects}

The observed group included children from two kindergartens and one primary school in Frýdek-Místek, and patients from the Orthopaedic prosthetic centre in Frýdek-Místek.

The experimental group consisted of children with bilateral heel valgus deformity (16 children, age $5.3 \pm 1.3$ years, height $112 \pm 12 \mathrm{~cm}$, weight $20.8 \pm 6.6 \mathrm{~kg}$ ) and children with unilateral heel valgus deformity (14 children, age $5.6 \pm 1.6$ years, height $117 \pm 11 \mathrm{~cm}$, weight $21.6 \pm 3.8 \mathrm{~kg}$ ). The control group consisted of 14 children (age $4.5 \pm 1.2$ years, height $106 \pm 8 \mathrm{~cm}$, weight $17.1 \pm 3.4 \mathrm{~kg})$.

\section{Procedure}

After the preliminary phase (signing of informed consent by the child's guardian and a questionnaire on any history of trauma or neurological or congenital developmental defects), an entrance examination of the child was conducted to determine the body weight and height of the child. Subsequently the evaluation of the child's somatotype and a tentative examination of the range of motion at the hip, knee and ankle joints were performed. The heel valgus angle was determined in standing position by a goniometer.

Pressure distribution on the foot during gait was analyzed by a two-metre long pressure plate Footscan (RSscan International, Olen, Belgium). Each subject performed at least 8 gait trials.

\section{Data processing}

For data processing, the Footscan gait software (version 7.97, RSScan International, Olen, Belgium) was used. Each foot was divided into 8 areas - the big toe (T1), the $1^{\text {st }}$ to $5^{\text {th }}$ metatarsals (M1, M2, M3, M4, M5) and the lateral and medial part of the heel (HL, HM).

The average values of variables pressure peak (MaxP), the relative time of pressure peak (time MaxP) and pressure impulse (Impulse) was calculated for each foot and area. The foot axis angle (the angle between foot axis and gait direction) was determined from the pressure distribution data.

The observed data was statistically processed in STATISTICA 10.0 (StatSoft, Inc., Tulsa, OK, USA). To determine the differences between the groups, we used the MannWhitney U test. For comparing the valgus and non-valgus limb in the group of unilateral heel valgus, the Wilcoxon test was performed. The Spearman correlation was used for evaluating the correlations between the foot axis position and the pressure variables. The $P$ value of less than 0.05 was deemed as significant.

\section{RESULTS}

\section{Rearfoot area}

For groups without valgus and with bilateral valgus heel position, no significant differences were found (TABLE 1). In the group with unilateral valgus heel, we found lowered pressure peak (MaxP) of the medial heel $(p<0.05)$ and increased pressure peak of the lateral heel $(p<0.01)$ in the limb with valgus heel position (TABLE 2).

\section{Forefoot area}

For the group with bilateral valgus heel position, we found significantly greater relative time of pressure peak in the big toe, significantly greater pressure peak and pressure impulse in the $1^{\text {st }}$ metatarsal $(p<0.01$, TABLE 3 ) and significantly lower pressure peak in the $4^{\text {th }}$ metatarsal $(p<0.05$, TABLE 3$)$. In the group of subjects with unilateral valgus heel in the valgus limb, significantly greater pressure peak $(p<0.05)$ and relative time of pressure peak $(p<0.01$, TABLE 4$)$ in the $3^{\text {rd }}$ metatarsal was detected. For the $4^{\text {th }}$ metatarsal we found on this limb significantly greater value for pressure impulse $(p<0.05)$, for the $5^{\text {th }}$ metatarsal greater pressure peak $(p<0.05)$ and pressure impulse $(p<0.01)$.

\section{DISCUSSION}

A pathological position of the foot leads to nonuniform body weight distribution (Vařeka \& Vařeková, 2005). Increased load in the medial part of the foot occurs during malfunctioning of the foot arch (Han et al., 2011; Ledoux \& Hillstrom, 2002; Valmassy, 1996; etc.). Inadequate pressure distribution at the foot's 
TABLE 1

Rearfoot loading and comparison of the groups with bilateral valgus and non-valgus heel position

\begin{tabular}{|l|l|r|r|r|r|r|}
\hline \multirow{2}{*}{ Area } & \multirow{2}{*}{ Parameter } & \multicolumn{2}{|c|}{ C } & \multicolumn{2}{|c|}{ V } & \multirow{2}{*}{$\boldsymbol{p}$} \\
\cline { 3 - 6 } & & Mean & SD & Mean & SD & \\
\hline \multirow{4}{*}{ HM } & MaxP $\left[\mathrm{N} \times \mathrm{cm}^{-2}\right]$ & 9.0 & 2.1 & 9.9 & 2.5 & 0.211 \\
\cline { 2 - 6 } & Time MaxP $[\%]$ & 16.0 & 4.8 & 15.7 & 4.7 & 0.773 \\
\cline { 2 - 6 } & Impulse $\left[\mathrm{N} \times \mathrm{s} \times \mathrm{cm}^{-2}\right]$ & 1.5 & 0.5 & 1.6 & 0.6 & 0.641 \\
\hline \multirow{4}{*}{ HL } & MaxP $\left[\mathrm{N} \times \mathrm{cm}^{-2}\right]$ & 6.5 & 1.5 & 7.1 & 1.6 & 0.129 \\
\cline { 2 - 7 } & Time MaxP $[\%]$ & 17.3 & 5.8 & 15.8 & 5.0 & 0.303 \\
\cline { 2 - 7 } & Impulse $\left[\mathrm{N} \times \mathrm{s} \times \mathrm{cm}^{-2}\right]$ & 1.1 & 0.5 & 1.2 & 0.4 & 0.609 \\
\hline
\end{tabular}

Legend: $\mathrm{C}$ - control group (non-valgus heel position), $\mathrm{V}$ - bilateral valgus heel position, $p$ - statistical significance level, SD - standard deviation, HM - medial heel, HL - lateral heel, MaxP - pressure peak, Time MaxP - time of pressure peak, Impulse - pressure impulse

TABLE 2

Rearfoot loading and comparison of limbs with valgus and non-valgus heel position

\begin{tabular}{|l|l|r|r|r|r|c|}
\hline \multirow{2}{*}{ Area } & \multirow{2}{*}{ Parameter } & \multicolumn{2}{|c|}{ U_N } & \multicolumn{2}{|c|}{ U_V } & \multirow{2}{*}{$\boldsymbol{p}$} \\
\cline { 2 - 6 } & & Mean & SD & Mean & SD & \\
\hline \multirow{4}{*}{ HM } & MaxP $\left[\mathrm{N} \times \mathrm{cm}^{-2}\right]$ & 11.0 & 2.3 & 10.4 & 2.1 & 0.041 \\
\cline { 2 - 6 } & Time MaxP $[\%]$ & 16.1 & 5.4 & 16.6 & 4.0 & 0.730 \\
\cline { 2 - 7 } & Impulse $\left[\mathrm{N} \times \mathrm{s} \times \mathrm{cm}^{-2}\right]$ & 1.8 & 0.6 & 1.6 & 0.4 & 0.056 \\
\hline \multirow{4}{*}{ HL } & MaxP $\left[\mathrm{N} \times \mathrm{cm}^{-2}\right]$ & 6.9 & 0.8 & 7.6 & 1.4 & 0.005 \\
\cline { 2 - 7 } & Time MaxP $[\%]$ & 15.2 & 6.4 & 15.1 & 5.3 & 0.551 \\
\cline { 2 - 7 } & Impulse $\left[\mathrm{N} \times \mathrm{s} \times \mathrm{cm}^{-2}\right]$ & 1.2 & 0.3 & 1.2 & 0.3 & 0.510 \\
\hline
\end{tabular}

Legend: U_N - limb with non-valgus heel position, U_V - limb with valgus heel position, $p$ - statistical significance level, SD - standard deviation, HM - medial heel, HL - lateral heel, MaxP - pressure peak, Time MaxP - time of pressure peak, Impulse - pressure impulse

area, often with valgus heel position, may cause medial deviation of the foot axis and also affect the position of the proximal body segments, especially at the hip joint and the pelvis (Duval, Lam, \& Sanderson, 2010; Franz, Paylo, Dicharry, Riley, \& Kerrigan, 2009; Khamis \& Yizhar, 2007; etc.). The greater part of the gait cycle takes place in the stance phase and only in this phase do the potential compensatory mechanisms of the body come into play (Vařeka \& Vařeková, 2005). Thus, the gait abnormalities may manifest in some degree of compensation as result of the problem (Whittle, 1996).

In this study, the differences in the loading of a child's foot between valgus and non-valgus heel position during gait were demonstrated. The comparison of the bilateral valgus and non-valgus group showed increased loading in the forefoot area (big toe, first metatarsal) and lowered loading in the fourth metatarsal in the valgus group. Ledoux and Hillstrom (2002) found increased loading below the big toe in bilateral valgus heel position, with general overloading of the first foot ray. Han et al. (2011) found significant reduction in foot loading in the fourth and fifth metatarsals and in the lateral part of the heel in bilateral flatfoot. Their conclusion correlates with the results of our study.

In our case, similar to the study by Ledoux and Hillstrom (2002), the forefoot becomes the site for possible loading compensation. It results in inadequate distribution of the body weight, which is reflected in dysfunction of the normal foot function (Brodtkorb, Kogler, \& Arndt, 2008). The rearfoot is not able to cooperate with the forefoot and thus cannot prevent its inappropriate loading.

The comparison of limbs with valgus and non-valgus heel position in the group with unilateral valgus heel position showed significant changes in the forefoot and the rearfoot. In the third to fifth metatarsal, significantly greater loading was found on the limb with valgus heel. The reason may be the necessity to enlarge the support base due to instability of the affected foot (Véle, 2006).

Increased loading in the third metatarsal head was presented by Vařeka and Vařeková (2005). Reduced medial arch is often associated with metatarsal pain, most often with pain in the second and the third metatarsal heads. However, there is lack of scientific studies 
TABLE 3

Values of the forefoot loading and comparison of differences for groups with bilateral valgus and non-valgus heel position

\begin{tabular}{|c|c|c|c|c|c|c|}
\hline \multirow{2}{*}{ Area } & \multirow{2}{*}{ Parameter } & \multicolumn{2}{|c|}{ C } & \multicolumn{2}{|c|}{ V } & \multirow{2}{*}{$p$} \\
\hline & & Mean & SD & Mean & SD & \\
\hline \multirow{3}{*}{ T1 } & $\operatorname{MaxP}\left[\mathrm{N} \times \mathrm{cm}^{-2}\right]$ & 5.0 & 2.0 & 5.9 & 1.8 & 0.072 \\
\hline & Time MaxP [\%] & 81.5 & 2.9 & 83.7 & 2.5 & 0.004 \\
\hline & Impulse $\left[\mathrm{N} \times \mathrm{s} \times \mathrm{cm}^{-2}\right]$ & 0.7 & 0.3 & 0.7 & 0.3 & 0.386 \\
\hline \multirow{3}{*}{ M1 } & $\operatorname{MaxP}\left[\mathrm{N} \times \mathrm{cm}^{-2}\right]$ & 4.6 & 1.4 & 6.0 & 2.1 & 0.004 \\
\hline & Time MaxP [\%] & 65.6 & 7.3 & 69.3 & 5.6 & 0.070 \\
\hline & Impulse $\left[\mathrm{N} \times \mathrm{s} \times \mathrm{cm}^{-2}\right]$ & 0.9 & 0.4 & 1.3 & 0.6 & 0.014 \\
\hline \multirow{3}{*}{ M2 } & $\operatorname{MaxP}\left[\mathrm{N} \times \mathrm{cm}^{-2}\right]$ & 8.1 & 2.0 & 8.1 & 2.2 & 0.853 \\
\hline & Time MaxP [\%] & 71.7 & 4.8 & 74.1 & 4.2 & 0.077 \\
\hline & Impulse $\left[\mathrm{N} \times \mathrm{s} \times \mathrm{cm}^{-2}\right]$ & 1.6 & 0.6 & 1.6 & 0.6 & 0.947 \\
\hline \multirow{3}{*}{ M3 } & $\operatorname{MaxP}\left[\mathrm{N} \times \mathrm{cm}^{-2}\right]$ & 8.1 & 2.4 & 7.1 & 2.4 & 0.072 \\
\hline & Time MaxP [\%] & 70.7 & 5.6 & 70.7 & 5.5 & 0.876 \\
\hline & Impulse $\left[\mathrm{N} \times \mathrm{s} \times \mathrm{cm}^{-2}\right]$ & 1.6 & 0.6 & 1.4 & 0.5 & 0.153 \\
\hline \multirow{3}{*}{ M4 } & $\operatorname{MaxP}\left[\mathrm{N} \times \mathrm{cm}^{-2}\right]$ & 6.2 & 2.3 & 5.2 & 2.0 & 0.037 \\
\hline & Time MaxP [\%] & 65.0 & 8.4 & 63.5 & 8.8 & 0.630 \\
\hline & Impulse $\left[\mathrm{N} \times \mathrm{s} \times \mathrm{cm}^{-2}\right]$ & 1.2 & 0.5 & 1.0 & 0.4 & 0.074 \\
\hline \multirow{3}{*}{ M5 } & $\operatorname{MaxP}\left[\mathrm{N} \times \mathrm{cm}^{-2}\right]$ & 2.1 & 1.3 & 1.9 & 1.1 & 0.795 \\
\hline & Time MaxP [\%] & 59.0 & 10.1 & 57.1 & 9.7 & 0.354 \\
\hline & Impulse $\left[\mathrm{N} \times \mathrm{s} \times \mathrm{cm}^{-2}\right]$ & 0.3 & 0.2 & 0.3 & 0.2 & 0.568 \\
\hline
\end{tabular}

Legend: C - control group (non-valgus heel position), V - experimental group (bilateral valgus heel position), $p$ - statistical significance level, SD - standard deviation, T1 - big toe, M1 to M5 - metatarsal heads, MaxP - maximum immediate loading, Time MaxP - percentage of stance phase time during the walking, Impulse - loading during foot roll

focused on limbs comparison in groups with unilateral heel valgus.

Regarding the correlation between the position of foot axis and heel valgus, we found significant difference in the group with unilateral valgus heel position where the foot axis was rotated more medially in the limb with valgus heel position. This correlates with the results of Han et al. (2011), which states medial foot deviation in the flatfoot. However, the authors presented the results concerning bilateral valgus and non-valgus groups. In our research, we found the tendency of the foot axis to rotate towards the medial part of the foot in the bilateral heel valgus group; however, the correlation was not significant.

Greater loading on the limb without valgus heel position is key to understanding the flatfoot issue in general. It indicates the possibility of incorrect perception of the flatfoot problem as a local foot disability. This understanding of flatfoot is confirmed also by the studies related to the hip and the pelvis, which are, with regard to the foot, "distant" segments (Fubry, 2010). The foot as the terminal segment is an important part of the postural system of the entire body. Therefore, it is important to observe these relations in a wider context, especially in cases where the foot is a key segment in the dynamics of the whole body (Chuter \& Janse de Jonge, 2012; Kapandji, 1987; Lewit \& Lepšíková, 2008; Vařeka \& Vařeková, 2012).

Understanding the correlations should help in more efficient treatment of foot pathologies not only in children but also in adults. In children, through early diagnosis and proper treatment (orthotics + active exercise), we can reduce the range of possible musculoskeletal compensations in adulthood when the human body, pursuant to inappropriate setting of the individual segments, is exposed not only to physical but also mental stress. Cetin, Sevil, Karaoglu, and Yucekaya (2011) reported that $90 \%$ of flatfoot in children should not be treated, but this problem may not be seen only as an exclusive problem of growth. Additionally, we assume that this number will decrease rapidly due to the current trend of children's physical deprivation reaching epidemic proportions.

In flatfoot diagnosis, physicians often focus in the foot area; in some cases in the proximal body segments. However, even these segments can be affected not only 
TABLE 4

Values of forefoot loading and comparison of the differences for limbs with valgus and non-valgus heel position in the group with unilateral valgus heel

\begin{tabular}{|c|c|c|c|c|c|c|}
\hline \multirow{2}{*}{ Area } & \multirow{2}{*}{ Parameter } & \multicolumn{2}{|c|}{ U_N } & \multicolumn{2}{|c|}{$\mathbf{U}_{-} \mathbf{V}$} & \multirow{2}{*}{$p$} \\
\hline & & Mean & SD & Mean & SD & \\
\hline \multirow{3}{*}{ T1 } & $\operatorname{MaxP}\left[\mathrm{N} \times \mathrm{cm}^{-2}\right]$ & 5.0 & 2.0 & 5.1 & 1.8 & 0.826 \\
\hline & Time MaxP [\%] & 81.6 & 4.3 & 81.9 & 3.1 & 0.683 \\
\hline & Impulse $\left[\mathrm{N} \times \mathrm{s} \times \mathrm{cm}^{-2}\right]$ & 0.7 & 0.4 & 0.6 & 0.2 & 0.638 \\
\hline \multirow{3}{*}{ M1 } & $\operatorname{MaxP}\left[\mathrm{N} \times \mathrm{cm}^{-2}\right]$ & 5.3 & 2.0 & 4.6 & 1.5 & 0.363 \\
\hline & Time MaxP [\%] & 67.8 & 7.5 & 66.5 & 4.6 & 0.470 \\
\hline & Impulse $\left[\mathrm{N} \times \mathrm{s} \times \mathrm{cm}^{-2}\right]$ & 1.1 & 0.5 & 1.0 & 0.3 & 0.433 \\
\hline \multirow{3}{*}{ M2 } & $\operatorname{MaxP}\left[\mathrm{N} \times \mathrm{cm}^{-2}\right]$ & 8.1 & 2.1 & 8.2 & 1.7 & 0.594 \\
\hline & Time MaxP [\%] & 74.7 & 4.9 & 73.7 & 3.5 & 0.363 \\
\hline & Impulse $\left[\mathrm{N} \times \mathrm{s} \times \mathrm{cm}^{-2}\right]$ & 1.6 & 0.6 & 1.8 & 0.6 & 0.074 \\
\hline \multirow{3}{*}{ M3 } & $\operatorname{MaxP}\left[\mathrm{N} \times \mathrm{cm}^{-2}\right]$ & 6.6 & 2.2 & 8.3 & 2.1 & 0.013 \\
\hline & Time MaxP [\%] & 69.7 & 7.7 & 71.3 & 5.6 & 0.002 \\
\hline & Impulse $\left[\mathrm{N} \times \mathrm{s} \times \mathrm{cm}^{-2}\right]$ & 1.3 & 0.5 & 1.7 & 0.5 & 0.331 \\
\hline \multirow{3}{*}{ M4 } & $\operatorname{MaxP}\left[\mathrm{N} \times \mathrm{cm}^{-2}\right]$ & 5.0 & 2.9 & 6.3 & 2.3 & 0.064 \\
\hline & Time MaxP [\%] & 60.6 & 14.3 & 62.4 & 11.0 & 0.331 \\
\hline & Impulse $\left[\mathrm{N} \times \mathrm{s} \times \mathrm{cm}^{-2}\right]$ & 0.9 & 0.7 & 1.3 & 0.5 & 0.019 \\
\hline \multirow{3}{*}{ M5 } & $\operatorname{MaxP}\left[\mathrm{N} \times \mathrm{cm}^{-2}\right]$ & 1.7 & 1.3 & 3.2 & 2.4 & 0.022 \\
\hline & Time MaxP [\%] & 54.9 & 15.9 & 55.2 & 11.9 & 0.975 \\
\hline & Impulse $\left[\mathrm{N} \times \mathrm{s} \times \mathrm{cm}^{-2}\right]$ & 0.3 & 0.2 & 0.6 & 0.6 & 0.006 \\
\hline
\end{tabular}

Legend: U_N - limb with non-valgus heel position (group with unilateral valgus heel position), U_V - limb with valgus heel position (group with unilateral valgus heel position), $p$ - statistical significance level, SD - standard deviation, T1 - big toe, M1 to M5 - metatarsal heads, MaxP - maximum immediate loading, Time MaxP - percentage of stance phase time during walking, Impulse - loading during foot roll

secondarily pursuant to foot dysfunction but also can be the source of the primary problem (for example, due to inadequate motor development in ontogenesis). Duval, Lam, and Sanderson (2010), Franz et al. (2009), Khamis and Yizhar (2007) and the others emphasize the relation of foot pathology, not only for children's foot, to the proximal segments and their influence on foot positioning. Understanding foot function, its vertical loading and the possible compensatory mechanisms in the proximal segments of the lower limbs and pelvis, can help prevent movement dysfunctions, especially childhood muscle imbalances impacting later in adulthood.

The limitations of this study can be attributed mainly to the difficulties in data collection, which were given mainly by the character of the research sample (children aged from 3 to 8 years). As part of the initial examination, it was not possible to include questions regarding psychomotor development or laterality. This information should improve the complexity of the knowledge of the study and should be used in following data analysis.
Interesting directions for future research would be to evaluate the movement of the center of pressure during gait which is typical for evaluation of static balance in various groups of patients (Schwabova et al., 2012). New findings can attempt the assessment of relationships between pressures in various foot areas in time. This procedure is typical for kinematics and use cyclograms or angle-angle diagrams (Kutilek \& Viteckova, 2012).

\section{CONCLUSION}

For the groups of children with valgus and non-valgus heel position, differences exist in foot loading during the gait cycle. The group with bilateral valgus heel loads more area of the big toe and the first metatarsal. In the group with unilateral valgus heel, the limb with heel valgus is less loaded except for the area of the third to fifth metatarsal. Foot axis in the limb with heel valgus is more rotated in the medial direction.

The foot as the distal segment of lower limb chain is a source of information about contact areas. There- 
fore, the outcomes of dynamic pressure distribution analysis should not be considered only as information concerning the foot but as data on the whole body.

Due to the range of changes, which the child's foot passes in this age, it seems necessary to provide several similar measurements on the same sample of children in the following 5 years.

\section{ACKNOWLEDGEMENT}

This work was supported by the Ministry of Education, Youth and Sport of the Czech Republic [grant number MSM 6198959221] and internal grant of the Faculty of Physical Culture, Palacký University [grant number FTK_2012_008].

\section{REFERENCES}

Brodtkorb, T. H., Kogler, G. F., \& Arndt, A. (2008). The influence of metatarsal support height and longitudinal axis position on plantar foot loading. Clinical Biomechanic, 23(5), 640-647.

Cetin, A., Sevil, S., Karaoglu, L., \& Yucekaya, B. (2011). Prevalence of flat foot among elementary school students, in rural and urban areas and at suburbs in Anatolia. European Journal of Orthopaedic Surgery \& Traumatology, 21(5), 327-331.

Chuter, V. H., \& Janse de Jonge, X. A. K. (2012). Proximal and distal contributions to lower extremity injury: A rewiew of the literature. Gait \& Posture, 36(1), 7-15.

Dungl, P. et al. (2005). Ortopedie. Praha: Grada Publishing.

Duval, K., Lam, T., \& Sanderson, D. (2010). The mechanical relationship between the rearfoot, pelvis and low-back. Gait \& Posture, 32(4), 637-640.

Franz, J. R., Paylo, K. W., Dicharry, J., Riley, P. O., \& Kerrigan, D. C. (2009). Changes in the coordination of hip and pelvic kinematics with mode of locomotion. Gait \& Posture, 29(3), 494-498.

Fubry, G. (2010). Clinical practise: static, axial, and rotational deformities of the lower extremities in children. European Journal of Pediatrics, 169(5), 529-534.

Han, J. T., Koo, H. M., Jung, M. J., Kim, Y. J., \& Lee, J. H. (2011). Differences in plantar foot pressure and COP between flat and normal feet during walking. Journal of Physical Therapy Science, 23(4), 683-685.

Haris, G. F., Smith, P. A., \& Marks, R. M. (2008). Foot and ankle motion analysis. London: CRC Press.

Hoogvliet, P., van Duyl, W. A., de Bakker, J. V., Mulder, P. G. H., \& Stam, H. J. (1997). A model for the relation between the displacement of the ankle and the center of pressure in the frontal plane, during one-leg stance. Gait \& Posture, 6(1), 39-49.

Kapandji, I. A. (1987). The physiology of the joints: Volume two, lower limb. Edinburgh: Churchill Livingstone.

Khamis, S., \& Yizhar, Z. (2007). Effect of feet hyperpronation on pelvic alignment in a standing position. Gait \& Posture, 25(1), 127-134.

Kutilek, P., \& Viteckova, S. (2012). Prediction of lower extremity movement by cyclograms. Acta Polytechnica, 52(1), 51-60.

Ledoux, W. R., \& Hillstrom, H. J. (2002). The distributed plantar vertical force of neutrally aligned and pes planus feet. Gait \& Posture, 15(1), 1-9.

Lewit, K., \& Lepšíková, M. (2008). Chodidlo - významná část stabilizačního systému. Rehabilitace a fyzikální lékařství, 15(3), 99-104.

Perry, J., \& Burnfield, J. M. (2010). Gait analysis: Normal and pathological function (2nd ed.). Thorofare, NJ: SLACK Incorporated.

Schwabova, J., Zahálka, F., Komarek, V., Malý, T., Hráský, P., Gryc, T., Cakrt, O., \& Zumrová, A. (2012). Uses of the postural stability test for differential diagnosis of hereditary ataxias. Journal of the Neurological Sciences, 316(1-2), 79-86.

Valmassy, R. L. (1996). Clinical biomechanics of the lower extremities. St. Louis, MO: Mosby-Year Book, Inc.

Vařeka, I., \& Vařeková, R. (2005). Patokineziologie nohy a funkční ortézování. Rehabilitace a fyzikální lékařství, 12(4), 156-166.

Vařeka, I., \& Vařeková, R. (2009). Kineziologie nohy. Olomouc: Univerzita Palackého.

Vařeka, I., \& Vařeková, R. (2012). Sdružené pohyby kloubů dolní končetiny a reverze posunu kondylů femuru při zatížení. Rehabilitace a fyzikální lékařství, 19(1), 13-17.

Véle, F. (2006). Kineziologie. Praha: Triton.

Whittle, M. M. (1996). Gait Analysis: An introduction. Oxford: Butterworth-Heinemann.

Zafiropoulos, G., Prasad, K. S. R. K., Kouboura, T., \& Danis, G. (2009). Flat foot and femoral anteversion in children - a prospective study. The Foot, 19(1), 50-54.

\section{VLIV VALGÓZNÍHO POSTAVENÍ PATY NA ZATÍ- ŽENÍ DĚTSKÉ NOHY PŘI CHŮZI}

(Souhrn anglického textu)

VÝCHODISKA: Pro dětskou nohu je typický klinický obraz plochonoží, který se projevuje při vertikálním zatížení nohy jako valgózní postavení paty. To může 
vést $\mathrm{k}$ deviaci osy nohy mediálním směrem a způsobit přetižení vybraných oblastí na chodidle.

CÍLE: Určit vliv valgózního postavení paty (při oboustranné i při jednostranné valgozitě paty) na zatížení nohy při chůzi.

METODIKA: Experimentální soubor tvořily děti s oboustrannou valgozitou paty (16 dětí, průměrný věk 5,3 $\pm 1,3$ roku) a jednostrannou valgozitou paty (14 dětí, průměrný věk $5,6 \pm 1,6$ roku). Kontrolní skupinu tvořilo 14 dětí (průměrný věk $4,5 \pm 1,2$ roku). Pro měření zatížení nohy při chůzi byla použita plantografická plošina Footscan (RSScan International, Olen, Belgie). Každý proband absolvoval 8 pokusů chůze. Z každého pokusu bylo vyhodnoceno zatižení 8 oblastí na plosce nohy. Zpracování dat (průměrné hodnoty pro každý subjekt) bylo provedeno pomocí neparametrických testů (Mann-Whitney test, Wilcoxonův test, Spearmanův korelační koeficient) v programu STATISTICA (StatSoft, Inc., Tulsa, OK, USA).

VÝSLEDKY: Maximum tlaku a tlakový impuls v oblasti prvního metatarsu byly ve srovnání s kontrolní skupinou větší u skupiny s oboustrannou valgozitou paty $(p<0,01)$. U skupiny s jednostrannou valgozitou paty bylo zjištěno větší maximum tlaku v oblasti mediální části paty $(p<0,05)$, menší maximum tlaku $\mathrm{v}$ oblasti třetího metatarzu $(p<0,01)$, menší tlakový impuls v oblasti čtvrtého metatarzu $(p<0,05)$ a menší maximum tlaku $(p<0,05)$ a tlakový impuls $(p<0,01)$ v oblasti pátého metatarzu u končetiny bez valgozity paty.

ZÁVĚRY: Pro skupiny dětí s valgózním a nevalgózním postavením paty existuji rozdíly $\mathrm{v}$ zatížení nohy při chůzi. Práce poukazuje na nezbytnost komplexního řešení problému pro zamezení šíření patologických změn.

Klíčová slova: pata, zatízení, chůzový cyklus, dynamická plantografie, rozložení tlakủ.

\section{Mgr. Eliška Martinásková}

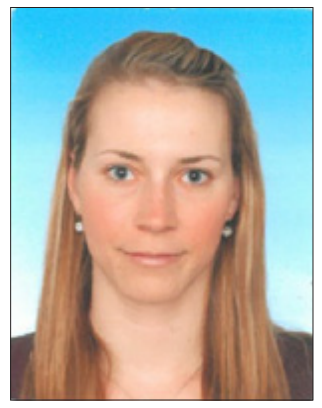

Palacký University, Olomouc

Faculty of Physical Culture

tř. Míru 115

77111 Olomouc

Czech Republic

Education and previous work experience

Since 2013 - research assistant, Faculty of Physical Culture, Palacký University, Olomouc.

Since May 2013 - physiotherapeutist, Moje rehabilitace s.r.o.),

2012-2013 - physiotherapeutist, Centrum rehabilitační péče Bohumín s.r.o.

2010-2013 - Faculty of Physical Culture, Palacký University, Olomouc, master's study programme - Physiotherapy.

2008-2010 - University of Lugano (Universitá della Svizzera italiana), bachelor's study programme - Physiotherapy.

2007-2010 - Faculty of Medicine, University of Ostrava, bachelor's study programme - Physiotherapy.

\section{First-line publications}

Kuboňová, E. (2010). Dysbalance svalů stabilizujicich páteř jako jedna z príčin bolestí zad. Bachelor thesis, University of Ostrava, Faculty of Medicine, Ostrava.

Martinásková, E. (2013). Vliv patologického postavení dětské nohy na její zatízení při chůzi. Master thesis, Palacký University, Olomouc, Faculty of Physical Culture, Olomouc. 